\title{
Saudi Youth University Graduates and Their Worries about the Future: A Field Study on Students of Saudi Universities in Riyadh
}

\author{
Abdulqader Abdullah Al-Orabi ${ }^{1}$, Maysoon Alfa'iz ${ }^{2, *}$ \\ ${ }^{1}$ Faculty of Social Planning, Princess Nourah bint Abdulrahman University, Riyadh, Saudi Arabia \\ ${ }^{2}$ Department of Sociology, State of Frankfurt University, Germany
}

\begin{abstract}
Worrying is a part of human nature and stems usually from personal, cultural, economic, and social reasons. This research is an attempt to examine the future worries of the students (both males and females) pursuing graduate studies in different universities of Saudi Arabia - King Saud University, Princess Nourah Bint Abdulrahman University, and Imam Mohammad ibn Saud Islamic University in Riyadh during the academic year (1436-1437 $\mathrm{H}$, that is, 2014-2015). Using a questionnaire survey and based on cluster sampling and psychological analysis, the research was conducted amongst 872 students out of 5486 students. The findings suggest that graduates of both genders suffer from future worries arising from fear of unemployment, socio-cultural and personal failure, which might bear detrimental effects on their health.
\end{abstract}

Keywords Graduate Students, Worry, Future, Education, Saudi Arabia

\section{Statement of the Problem}

Students' worries about their futures are highly under-researched in Saudi Arabia. Worrying is however a part of human nature and stems from during the times of crises, challenges, and changes in life (Bozyan and Bogsah, 2012; Linden, 2010; Peseschkian, 1998; Turiaux et al., 2014). Although, every individual is susceptible to some kind of worrying, it affects the youths most, especially those who are about to graduate. This is because graduation is a turning point in students' lives as it is a defining time that shapes students' future. The central aim of this research revolves around our everyday observations of the amount of pressures-academic, economic or socio-mental that the graduates go through, while performing their roles as students and simultaneously worrying for their futures.
These pressures increase gradually starting from early college years, where a distinct gap becomes visible between the academic style of high school and college. After that, students' worries become more future-oriented. These worries often interfere with their personal life. Of course, worries of women are different to those of men (see, for instance, Alfaltawi, 2007). A female graduate as she grows up usually suffer from the built-in worries based mainly on societal expectations of playing multiple overlapping roles. It is usually the woman, who remains at the center of society's judgment. This largely affects not only the academic performance of a female graduate but also social relationships and future worries. In the said context, Alfaltawi (2007: 96) said:

\section{[W] hen an individual is unable to determine one's future, one feels down and worried about oneself, one's existence, and one's relation with others. The study has showed that a good future involves success at work, self-development, and successful relations with others. (Alfaltawi, 2007: 96).}

This research aims to probe the worries of the youths. There is a large literature on students' worries elsewhere (Almasoud, 2005; Bozyan and Bogsah, 2012; Dawud and Others, 1991; Hasan, 2000; Hejazy, 2008; Laylah, 1995; Linden, 2010; Peseschkian, 1998; Turiaux et al., 2014). Scholars argue that there are many factors, which contribute to youths' worries and anxieties. As stated earlier, it is the very nature of the stage of their lives-platforms for preparation of the future leads to worries and anxieties. Besides, most youths being in their adolescence or late adolescence stage suffers from the gap between physical growth and social growth. This growth gap arises from the youths' physical growth and the society's recognition of the youth as an individual citizen, who is expected to play societal roles without creating any problems. Further, sensitivity of the individual youth and her/his sense of pride 
often hinder in their everyday life as most youths "are not open to criticism[s]" (Laylah, 1995: 194). In 2000, Hasain studied the future and exam worries of high school students and its impact on their mental health. Similarly, Nahed Almasoud (2005) examined the future worries amongst the students studying in Damascus University where the scholar argues that the key cause of anxiety and worry of these graduates stems from the dissatisfaction of the subject they had been pursuing and the inability to study the particular subject (the major) they initially wanted. "Such anxiety causes students to live a period distinguished by feeling down, losing motivation, and sensing hopelessness when it comes to their future as they do not find themselves in [subjects] that secure good job opportunities after graduation." (Hejazy, 2008: 53).

Hejazy (2008) goes on to argue that an employment is a road to self-worth and belonging, which making the individual feels socially and mentally secured. However, it is the transitional phase of the youths, in which the particular youth moves from a supported atmosphere to a culture of open competitions and accomplishments while entering into a mysterious future are somewhat worrisome (Hejazy, 2008). In addition, this worrying can be either normal or a part of a mental disorder and are likely to affect youths' identities (Hejazy, 2008). According to Erich Erkson, a famous German psychologist, these types of worries tear apart youths' identities (Hejazy, 2008: 63). While the past, its values, and traditions are the key ingredients to building an individual's personality, the future and its hopes and pains are the determinants to constructing the identity of an individual and future personality. In the light of these backdrops, the key aim of this research is to examine the future worries of Saudi youth university graduates. In trying to find answer to this research question, the other inter-linked questions were probed too- - the reasons behind the worries; the extent of these worries; future worries (if any); relationhips of the student's with her/his subject choice; the impact of the worries on a student's health; the relationships of future worries with future phobias; and graduates' attitudes towards facing worries. The next section describes the background to the study.

\section{Study Background}

In this section, we theorize various concepts and hypotheses that underpin this research. Worrying is different from similar cases like pain and fear. Worries and fears are usually synonymous words. A person fears inner and external dangers.

\section{a. Worrying}

One of the key concepts in psychology is worrying, which has led to multiple contemporary phenomena like anxiety, insomnia, and depression. These phenomena remain the factors in shaping the psychological status of the humans. It is however normal for humans to worry about things. Here, we aim to define the concept of worry in the same way as psychologists, sociologists, and scientists. The first person to study human psychology is Sigmund Freud. He defines worrying as: "a sensation occurs as a reaction to dangerous situations" (Freud, 1989: 109). The sensation of worrying is triggered with feeling a danger that threatens one's life or expecting an upcoming one. "Thus, worrying is initially something that we feel and regard as just a feeling, although we are not very clear on what to regard as a feeling. But if we were to regard worrying as a feeling, it is one that ruins one's day" (Freud, 1989: 116). Freud presented three types of worrying: rational, emotional, and moral (feeling guilty) (Haul, 1990: 71). These types are different from one another on the ground of source and effect. "Rational worries come from the external world." Emotional worries emerge from oneself. Moral worries are from a person's conscience, or noble ego." (Haul, 1990: 71). There are several other scholars, who have defined worrying.

Eragat Ferry defines worrying as "a mental and physical status of behavioral, emotional, and cognitive sides. These sides come together to create a deep sense of worries, fears, and negative anticipations resulting in creating a negative image of the future. During that, an individual usually focuses on painful past experiences" (Eragat, 2012: 67 and 68). It can be argued that the phenomenon of worrying is associated with feeling being scared, in peril or expecting some sort of danger. These worries are also associated with the future that is uncanny, but could precipitate mental challenges. Peseschkian(1998) however emphasizes that "the positive side of worrying is its power to manage life, like being aware of the importance of securing a life to avoid current dangerous, unpredicted situations. Worrying is a means to care for the future, as worries bring the will to change, change lives" (Peseschkian, 1998: 22).

\section{b. Future Worries}

It remains well documented that future dangers are the sources of future worries. Humans "naturally tend to remember and predict" (AlFatlawi, 2010: 9). According to Alder, a German scientist slightly contradicts Sigmund Freud's psychological analysis of future worries by stating that "humans are moved by future predictions more than past experiences. Life goals are the inner factors of psychological actions. Any theory is moved by a desire. Motives, forces, and desires can never be explained, yet they are the final conclusion of understanding human behaviors" (Houl and Tendra, 1978: 163 cited in AlFatlawi, 2010: 66). In short, Adler argued that desires and motives direct actions. Sigmund Freud however argued that individuals are driven by future and futuristic goals but worries emerge when the future turns into a source of fear and danger. The future is unpredictable and out of humans' control. Taking the arguments of the scientists on board, scholars simply believe 
that worries are the reactions of predicting certain incidents triggered by fear and discomfort towards what the future holds (Sawaleha, 2007; Shevromelman, 1989).

\section{c. The Hypothesis behind the Problem}

For this research, we frame two-hypothesis to examine the graduate students' worries about the future. However, before framing of the hypotheses, it is important to describe Psychological Analysis of Future Worries developed by Sigmund Freud.

\section{Freud's Psychological Analysis of Future Worries}

Sigmund Freud observed the increase of psychological disorders amongst individuals and used his theory of psychological analysis to describe that human psychological status as an independent branch of psychology, which studies humans and their reactions, emotions, fears and suppressions.

Worries are a central concept in Freud's theory of psychological analysis. Hence, he focused his studies in defining worries - that is, what is known as normal worries, sickly worries, symptoms of worrying, the differences between worrying and other concepts, and worrying's impact on health and behavior. In addition, Freud focused on specifying the concept of worrying as follows:

it is an irritating feeling... it is the fear and the anxiety caused by mystery and associated with a kind of physiological worrying... it is a reaction towards a dangerous situation" (Freud, 1989: 106, 107 and 108).

In Freud's perspective, danger is anything that threatens someone's life, similar to a child feeling endangered when his mother is gone. "The danger of psychological deficiency in one's life is when a person acts egotistically like an amateur." (See, Freud, 1989:118). Calvin Haul defines worrying as, "a painful emotional experience result[ing] from an inner reaction of the body. This reaction is the result of inner and external signals controlled by the nervous system." (Haul, 1990: 70).

Furthermore, worrying is associated with pain, sadness, and depression. Worries lead to sadness. "Sadness is a distinctive sort of pain." (Freud, 1989: 151). Feeling low is also a symptom of worrying. When an individual feels worried because of pressure from one's ego, one tries to decrease one's worries by blaming the external world for what one is experiencing. Instead of saying, "my conscience is bothering me, one would say, "you bother me" (Haul, 1990: 102). In this context, Haul (1990: 103) argues that "[t]his kind of self-defense against worrying is called projection."

Spiel Berger, who studied the traits of a worried personality proposed the theory of trait. It is he who distinguished between "worrying case," and "a trait of worrying." A case of worrying is when we feel worried towards a situation then stop after the situation has been dealt with or overcome. A trait of worries simply means preparation for a worrying situation. A case of worrying is an emotional case, where a person feels like one is facing a challenge. In other words, worrying trait is an acquired behavior of humans, which remains calm until inner or external threats occur. This kind of worrying is [usually] associated with early childhood experiences" (Algrity, 1998: 50) but can also emerge from individual ego and mysterious future.

In the light of these arguments, we frame our null hypothesis $\left(\mathrm{H}_{0}\right)$ that students do not suffer from rational and normal worries as a result of academic pressures and exams and $\mathrm{H}_{1}$ that there are gendered differences in men's and women's worries.

\section{The Method of the Study}

\section{- The Approach}

In this study, a descriptive approach is used. The descriptive approach depends on collecting both quantitative and qualitative data on the phenomenon of the study in order to understand, analyze, and explain it and its relation with other phenomena to reach a general statement.

\section{- The Subjects of the Study}

This study was conducted amongst 872 students from a total of 5486 graduate students of Princess Nourah University, King Saud University, and Imam Mohammad ibn Saud Islamic University. These students are in the second semester of the year $(1436-1437 \mathrm{H})$ and pursuing various subjects ranging from social sciences and humanities to scientific fields. The breakdowns of the number of students of the different universities are: 1631 graduates in King Saud University; 3002 graduates in Imam Mohammad ibn Saud Islamic University, and 853 students in Princess Nourah University.

- The overall sample of this study involves 276 graduates from King Saud University, 120 graduates from Princess Nourah University, and 476 graduates from Imam Mohammad ibn Saud Islamic University. Graduates are both from Humanities and Scientific fields. Indicators taken into consideration for this research are gender, age, major of study, social status, monthly income, and parents' level of education.

\section{- Study Sample}

In order to retrieve accurate information from this research, cluster-sampling technique was deployed using the three universities as three clusters that were further sub-divided into colleges, then into departments. Such sample suits the subjects of this study and allows us to reach the largest number of graduates possible. We could acquire the lists of university graduates from the offices of deanship of admission and registration of each respective university. 
Since most departments have had less than 20 graduates, we had to limit our sample and use percentage just to make sure the research society is similar to the research sample. Thus, we have counted the number of graduates until forty as a complete number; so, from (41-100) we registered $20 \%$, from (100-200) we registered as $10 \%$, and from (200 and above) we registered 5\%. Using this division leads to a total sample number of 863 in all three universities. However, we had to exclude 26 surveys because they were incomplete. This leaves us with a total sample of 387 graduates. Tables 1-7 makes detailed illustrations of the research.

Table 1. Distribution of the study sample among Departments of the Field of Humanities

\begin{tabular}{|c|c|c|}
\hline Department & Number of Graduates & Percentage \\
\hline Education & 47 & $5.6 \%$ \\
\hline English & 109 & $13.6 \%$ \\
\hline Arabic & 80 & $9.6 \%$ \\
\hline Sociology & 72 & $8.6 \%$ \\
\hline Community Service & 79 & $9.4 \%$ \\
\hline College of Community & 24 & $2.9 \%$ \\
\hline Shariah & 48 & $5.7 \%$ \\
\hline Total & 459 & $54.8 \%$ \\
\hline
\end{tabular}

Table 1 portrays that the English department has the highest number of graduates (109), which equals $13.6 \%$. This is followed by the Department of Arabic with 80 graduates, which stands at $9.6 \%$. The next Departments that follow the line are respectively the Department of Community Service with 79 graduates $(9.4 \%)$, Sociology department with 72 graduates (8.6\%), Shariah Department with 48 graduates $(5.7 \%)$, finally, the College of Education with 47 graduates $(5.6 \%)$ and the college of community with 24 graduates $(2.9 \%)$. The findings unveil that high percentage registered within the Department of English indicates that they are less likely to worry about the future as the English language skills are highly demanding in the workforce. The same reason applies to the Department of Arabic as Arabic is one of the main taught courses.

Table 2. Distribution of the study sample among Departments of Sciences:

\begin{tabular}{|c|c|c|}
\hline Department & $\begin{array}{c}\text { Number of } \\
\text { Graduates }\end{array}$ & Percentage \\
\hline Business Administration & 109 & $13.0 \%$ \\
\hline $\begin{array}{c}\text { Computer and Information } \\
\text { Sciences }\end{array}$ & 118 & $14.1 \%$ \\
\hline Banking & 22 & $2.6 \%$ \\
\hline Accounting & 41 & $4.9 \%$ \\
\hline Funding and Investing & 30 & $3.6 \%$ \\
\hline Economy & 58 & $6.9 \%$ \\
\hline Total & 378 & $45.2 \%$ \\
\hline
\end{tabular}

It is seen from Table 2 that the percentage of students studying Computer and Information Sciences graduates, stands at $14.1 \%$, which is highest in our research. Business and Administration graduates with a total of 109 students (or $13.0 \%$ ) follow this. Then comes the 58 (or $6.9 \%$ ) graduate students studying Economics. This is followed respectively by 30 graduates reading Funding and Investing (3.6\%) and
22 banking graduates with a percentage of $2.6 \%$.

From our research analysis, we could label that the subjects falling within the humanity fields as worrying fields of study, as science graduates are less likely to worry about their future. This is due to the increasing demands for graduates from scientific fields getting recruited within the rapidly growing oil-based economy of Saudi Arabia - the 2016 estimated Gross Domestic Product (GDP) of the country stands at $\$ 637.8$ billion; and in the same year the estimated GDP (purchasing power parity) stands at $\$ 1.731$ trillion over an estimated $\$ 1.711$ trillion in $2015 .{ }^{1}$

\section{Tools of the Study}

We designed our research taking into considerations of the theoretical parts on future worrying and the objectives of this study - the scale of future worries where we specified the following seven areas of determinations:

1. The level of future worrying amongst Saudi Youth University graduates.

2. The ratio of graduate students in the fields of Humanity and Scientific studies.

3. Reasons behind future worrying amongst graduates.

4. The relationships between future worrying and social phobia amongst graduates.

5. The impact of future worrying on the health of the graduates.

6. The ratio of future worrying and graduates based on gender.

7. The stance of Saudi youth graduates' towards worries about the future.

The scale of future worries in its final version consists of 60 points on seven different areas. Questions that are easier to understand are taken into consideration. Closed-ended questions bearing five-scale fixed multiple-choice answers complement the survey:

1. Strongly agree

2. Agree

3. No opinion

4. Disagree

5. Strongly disagree

Table 3 shows the distribution of the study sample of the three universities in Riyadh:

Table 3. The Distribution of the Study Sample of the Three Universities

\begin{tabular}{|c|c|c|}
\hline Category & Total & Percentage \\
\hline King Saud University & 266 & $31.8 \%$ \\
\hline Princess Nourah University & 120 & $14.3 \%$ \\
\hline $\begin{array}{c}\text { Imam Mohammad ibn Saud } \\
\text { Islamic University. }\end{array}$ & 451 & $53.9 \%$ \\
\hline Total & 837 & $100 \%$ \\
\hline
\end{tabular}

1 Saudi Arabia, The World Factbook, retrieved from, https://www.cia.gov/library/publications/the-world-factbook/geos/sa.html 
From this data (Table 3), we notice that over half of the samples are from Imam Mohammad ibn Saud Islamic University with $53.9 \%$, third of the sample, that is, $31.8 \%$ are from King Saud University, and the least percentage of the sample, $14.3 \%$ comes from Princess Nourah University.

\section{The Characteristics of the Study Sample}

Table 4. Distribution of the Study Sample in Accordance with Gender

\begin{tabular}{|c|c|c|}
\hline Category & Total & Percentage \\
\hline Males & 379 & $45.3 \%$ \\
\hline Females & 458 & $54.7 \%$ \\
\hline Total & 837 & $100 \%$ \\
\hline
\end{tabular}

Table 4 highlights the distribution of the study sample in accordance with gender. It shows that while the male graduates' percentage stands at $45.3 \%$, the percentage of female graduates are higher and stand at $54.6 \%$. This raises the possibility of studying the extent of worrying among male and female graduates, the factors that led to such variation, and this variation's relations with the mental, economic, and social factors.

Table 5. The Distribution of the Study Sample in Accordance with Major (Subject Specialization)

\begin{tabular}{|c|c|c|}
\hline Category & Total & Percentage \\
\hline Social and Humanity Studies & 558 & $66.7 \%$ \\
\hline Applied Sciences & 279 & $33.3 \%$ \\
\hline Total & 837 & $100 \%$ \\
\hline
\end{tabular}

It is apparent from Table 5 that the while the graduates pursuing social and humanities are nearly $66.7 \%$, which is around two-thirds of the sample, the percentage of graduates studying applied sciences stands at $33.3 \%$.

Table 6. The Distribution of the Study Sample in Accordance with Age

\begin{tabular}{|c|c|c|}
\hline Category & Total & Percentage \\
\hline 21 Years Old & 174 & $20.8 \%$ \\
\hline 22 Years Old & 256 & $31.7 \%$ \\
\hline 23 Years Old & 213 & $25.4 \%$ \\
\hline 24 Years Old and Over & 185 & $22.1 \%$ \\
\hline Total & 837 & $100 \%$ \\
\hline
\end{tabular}

Age-variation of the sample of graduates is highlighted in Table 6, which allows us to determine the statistical differences of the study scale. It appears that while nearly $32 \%$ are 22 years old, $25 \%$ are 23 years old and approximately $21 \%$ are 21 years old. Our analysis unfolds that having enrolled in higher education programs, these students are worried about their futures especially with respect to jobs and life after graduation including successful marriage. The oldest graduates (that is 24 years old and over) were found to be more worried than the younger ones especially the 21-year olds. This observation bears resonance to Abdulbagi's study, which showed that worrying "increases with one's age." (Abdulbagi, 1993: 120).

Table 7. The Distribution of the Study Sample in Accordance with the Monthly Income of the Family

\begin{tabular}{|c|c|c|}
\hline Category & Total & Percentage \\
\hline Less than 5000 & 84 & $10.0 \%$ \\
\hline From 5000 to less than 10000 & 277 & $33.1 \%$ \\
\hline From 10000 to less than 15000 & 228 & $27.2 \%$ \\
\hline From 15000 to less than 20000 & 128 & $15.3 \%$ \\
\hline From 20000 and more & 120 & $14.3 \%$ \\
\hline Total & 837 & $100 \%$ \\
\hline
\end{tabular}

The sample division in accordance with families' monthly incomes is shown in Table 7. Third of the sample, that is, $33.1 \%$ hails from those families that have monthly incomes between 5000 to less than 10000 S.R. Then over quarter of the sample, $27.2 \%$ are from families whose monthly incomes are in between 10000 to less than 15000 S.R. 15.3\% belongs to families whose monthly incomes ranges from 15000 to less than 20000 S.R, while $14.3 \%$ hails from rich families, whose incomes are over 20000 S.R. Finally, half of the sample belongs to the families whose monthly incomes ranges from 5000 to 15000 S.R. The findings of the research are discussed in the results and discussion section, which follows next.

\section{Results and Discussions}

One of the first questions of our research was to examine the extent of future worries amongst university youths, which are portrayed in Table 8 . 
Table 8. The Extent of Future Worrying Amongst Saudi Youths

\begin{tabular}{|c|c|c|c|c|c|c|c|c|c|c|}
\hline \multicolumn{3}{|c|}{ Statement } & $\begin{array}{c}\text { Strongly } \\
\text { agree }\end{array}$ & Agree & $\begin{array}{c}\text { No } \\
\text { opinion }\end{array}$ & Disagree & $\begin{array}{c}\text { Strongly } \\
\text { disagree }\end{array}$ & $\bar{x}$ & S & Sequence \\
\hline \multirow[t]{2}{*}{1.} & \multirow{2}{*}{$\begin{array}{l}\text { I feel worried about the future when I think } \\
\text { about working. }\end{array}$} & $\#$ & 269 & 380 & 35 & 113 & 40 & \multirow{2}{*}{3.87} & \multirow{2}{*}{1.15} & \multirow{2}{*}{4} \\
\hline & & $\%$ & 32.1 & 45.4 & 4.2 & 13.5 & 4.8 & & & \\
\hline \multirow[t]{2}{*}{2.} & \multirow{2}{*}{$\begin{array}{l}\text { I feel worried and tensed around graduation } \\
\text { time. }\end{array}$} & $\#$ & 158 & 313 & 97 & 196 & 73 & \multirow{2}{*}{3.34} & \multirow{2}{*}{1.26} & \multirow{2}{*}{8} \\
\hline & & $\%$ & 18.9 & 37.4 & 11.6 & 23.4 & 8.7 & & & \\
\hline \multirow[t]{2}{*}{3.} & \multirow{2}{*}{$\begin{array}{l}\text { I am worried about the limited job } \\
\text { opportunities. }\end{array}$} & $\#$ & 290 & 325 & 56 & 127 & 39 & \multirow{2}{*}{3.84} & \multirow{2}{*}{1.19} & \multirow{2}{*}{5} \\
\hline & & $\%$ & 34.6 & 38.8 & 6.7 & 15.2 & 4.7 & & & \\
\hline \multirow[t]{2}{*}{4.} & \multirow{2}{*}{$\begin{array}{l}\text { I am worried about not having a successful } \\
\text { marriage in the future. }\end{array}$} & $\#$ & 115 & 216 & 154 & 235 & 117 & \multirow{2}{*}{2.97} & \multirow{2}{*}{1.28} & \multirow{2}{*}{14} \\
\hline & & $\%$ & 13.7 & 25.8 & 18.4 & 28.1 & 14.0 & & & \\
\hline \multirow[t]{2}{*}{5.} & \multirow{2}{*}{$\begin{array}{l}\text { I am worried about being unable to fulfill all my } \\
\text { future financial needs. }\end{array}$} & $\#$ & 161 & 286 & 127 & 211 & 52 & 325 & 122 & 7 \\
\hline & & $\%$ & 19.2 & 34.2 & 15.2 & 25.2 & 6.2 & 3.35 & 1.22 & 1 \\
\hline 6 & I am worriced about mu family's future & $\#$ & 163 & 285 & 112 & 209 & 68 & 323 & 126 & 10 \\
\hline 0. & I am worried about my family’s future. & $\%$ & 19.5 & 34.1 & 13.4 & 25.0 & 8.1 & 3.32 & 1.26 & 10 \\
\hline 7. & I feel mental and social pressures caused by my & $\#$ & 111 & 235 & 111 & 258 & 122 & 205 & 130 & 15 \\
\hline & family's worries about me. & $\%$ & 13.3 & 28.1 & 13.3 & 30.8 & 14.6 & 2.95 & 1.30 & 15 \\
\hline 8. & I feel worried and unsafe about my future & $\#$ & 160 & 298 & 99 & 221 & 59 & 3.33 & 125 & 0 \\
\hline & financials. & \# & 19.1 & 35.6 & 11.8 & 26.4 & 7.0 & 3.33 & 1.25 & 9 \\
\hline 9. & I feel worried when I think about planning my & $\#$ & 170 & 373 & 90 & 157 & 47 & 255 & 117 & 6 \\
\hline & future. & $\%$ & 20.3 & 44.6 & 10.8 & 18.8 & 5.6 & 3.53 & $1.1 /$ & 0 \\
\hline 10 & Iom worriod ohout foiling in the future & \# & 164 & 296 & 95 & 204 & 78 & 232 & 120 & 11 \\
\hline 10. & I am worried about raning in the iuture. & $\%$ & 19.6 & 35.4 & 11.4 & 24.4 & 9.3 & 3.32 & 1.29 & 11 \\
\hline 11. & I am worried about not finding a suitable life & $\#$ & 154 & 201 & 152 & 211 & 119 & 307 & 134 & 13 \\
\hline & partner. & $\%$ & 18.4 & 24.0 & 18.2 & 25.2 & 14.2 & 3.07 & 1.34 & 13 \\
\hline 12. & I always think about the future even during & $\#$ & 176 & 283 & 66 & 212 & 100 & 227 & 126 & 12 \\
\hline & summer vacations. & $\%$ & 21.0 & 33.8 & 7.9 & 25.3 & 11.9 & 3.27 & 1.36 & 12 \\
\hline & $J$ & $\#$ & 78 & 112 & 121 & 304 & 222 & 2010 & 107 & 17 \\
\hline 13. & 1 see my future with pessimism. & $\%$ & 9.3 & 13.4 & 14.5 & 36.3 & 26.5 & 2.43 & 1.27 & 17 \\
\hline 14. & I see my studies as means of opening future & $\#$ & 326 & 363 & 62 & 65 & 21 & 408 & 100 & 1 \\
\hline & gates. & $\%$ & 38.9 & 43.4 & 7.4 & 7.8 & 2.5 & 4.08 & 1.00 & 1 \\
\hline 15 & 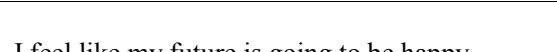 & $\#$ & 237 & 409 & 131 & 47 & 13 & 207 & 000 & 2 \\
\hline & 1 teen like my ruture is going to be happy. & $\%$ & 28.3 & 48.9 & 15.7 & 5.6 & 1.6 & 3.91 & 0.90 & 3 \\
\hline 16 & Lo & $\#$ & 273 & 392 & 83 & 67 & 22 & 200 & 000 & 2 \\
\hline & 1 am optimistic/ naturally an optimist. & $\%$ & 32.6 & 46.8 & 9.9 & 8.0 & 2.6 & 3.99 & 0.99 & 2 \\
\hline & & $\#$ & 45 & 77 & 78 & 294 & 343 & & & \\
\hline 17. & My studies are waste of time. & $\%$ & 5.4 & 9.2 & 9.3 & 35.1 & 41.0 & 2.03 & 1.16 & 20 \\
\hline 18. & I do not want to study because of my worrying & $\#$ & 48 & 95 & 83 & 332 & 279 & & & 18 \\
\hline & thoughts about the future. & $\%$ & 5.7 & 11.4 & 9.9 & 39.7 & 33.3 & 2.16 & 1.17 & 18 \\
\hline 19. & I feel like life opportunities for me are & $\#$ & 76 & 172 & 119 & 298 & 172 & 262 & 127 & 16 \\
\hline & decreasing. & $\%$ & 9.1 & 20.5 & 14.2 & 35.6 & 20.5 & 2.62 & 1.21 & 16 \\
\hline & Thou is nothing thet motive mo the & $\#$ & 48 & 82 & 67 & 331 & 309 & 200 & 116 & 10 \\
\hline 20. & There is nothing that motivates me to study. & $\%$ & 5.7 & 9.8 & 8.0 & 39.5 & 36.9 & 2.08 & 1.16 & 19 \\
\hline & & Ine & Iverage & .18( & inion) & & & & & \\
\hline
\end{tabular}


Table 9. The Relations between Future Worries and Major of Study (subject specialization)

\begin{tabular}{|c|c|c|c|c|c|c|c|c|c|c|}
\hline \multicolumn{3}{|c|}{ Statement } & $\begin{array}{c}\text { Strongly } \\
\text { agree }\end{array}$ & Agree & $\begin{array}{c}\text { No } \\
\text { opinion }\end{array}$ & Disagree & $\begin{array}{l}\text { Strongly } \\
\text { disagree }\end{array}$ & $\bar{x}$ & $\mathrm{~S}$ & Sequence \\
\hline \multirow{2}{*}{21.} & \multirow{2}{*}{ Society does not value humanity studies. } & \# & 220 & 288 & 123 & 144 & 62 & \multirow{2}{*}{3.55} & \multirow{2}{*}{1.25} & \multirow{2}{*}{2} \\
\hline & & $\%$ & 26.3 & 34.4 & 14.7 & 17.2 & 7.4 & & & \\
\hline \multirow{2}{*}{22.} & \multirow{2}{*}{ My major is art that does not provide a living. } & \# & 85 & 183 & 147 & 266 & 156 & \multirow{2}{*}{2.73} & \multirow{2}{*}{1.27} & \multirow{2}{*}{8} \\
\hline & & $\%$ & 10.2 & 21.9 & 17.6 & 31.8 & 18.6 & & & \\
\hline 23. & $\begin{array}{l}\text { Academic excellence is the means to future } \\
\text { success. }\end{array}$ & \# & 343 & 293 & 66 & 106 & 29 & 3.97 & 1.14 & 1 \\
\hline \multirow[t]{2}{*}{24.} & \multirow{2}{*}{$\begin{array}{l}\text { Many things stopped me from choosing the } \\
\text { right major. }\end{array}$} & \# & 187 & 242 & 88 & 212 & 108 & \multirow{2}{*}{3.22} & \multirow{2}{*}{1.38} & \multirow{2}{*}{4} \\
\hline & & $\%$ & 22.3 & 28.9 & 10.5 & 25.3 & 12.9 & & & \\
\hline \multirow[t]{2}{*}{25.} & \multirow{2}{*}{$\begin{array}{l}\text { I do not find my studies to be fulfilling of my } \\
\text { intellectual ambitions. }\end{array}$} & \# & 97 & 201 & 119 & 313 & 107 & \multirow{2}{*}{2.84} & \multirow{2}{*}{1.25} & \multirow{2}{*}{7} \\
\hline & & $\%$ & 11.6 & 24.0 & 14.2 & 37.4 & 12.8 & & & \\
\hline \multirow[t]{2}{*}{26.} & \multirow{2}{*}{$\begin{array}{l}\text { Teaching methods and curriculums do not } \\
\text { prepare me to be a researcher. }\end{array}$} & \# & 129 & 241 & 171 & 220 & 76 & \multirow{2}{*}{3.15} & \multirow{2}{*}{1.23} & \multirow{2}{*}{5} \\
\hline & & $\%$ & 15.4 & 28.8 & 20.4 & 26.3 & 9.1 & & & \\
\hline 27. & I feel trapped in my major. & $\%$ & 12.9 & 17.8 & 12.1 & 33.6 & 23.7 & 2.03 & 1.30 & 9 \\
\hline 28. & Many graduates from my major do not have & \# & 195 & 240 & 171 & 176 & 55 & 341 & 123 & 3 \\
\hline & jobs. & $\%$ & 23.3 & 28.7 & 20.4 & 21.0 & 6.6 & .41 & 1.23 & 3 \\
\hline 29. & I feel like our curriculums do not teach us to be & $\#$ & 124 & 256 & 126 & 236 & 95 & 300 & 128 & 6 \\
\hline & independent . & $\%$ & 14.8 & 30.6 & 15.1 & 28.2 & 11.4 & 3.09 & 1.20 & 6 \\
\hline 30. & My disinterest in my major is the reason behind & $\#$ & 67 & 105 & 124 & 265 & 276 & 231 & 127 & 10 \\
\hline & my absence from lectures. & $\%$ & 8.0 & 12.5 & 14.8 & 31.7 & 33.0 & & & 10 \\
\hline & & ener & Average $=$ & $3.09(\mathrm{~N}$ & pinion) & & & & & \\
\hline
\end{tabular}

From our analysis, it appears that $77 \%$ of the graduates are worried when they think about their future (Table 8). In addition, $56.1 \%$ of the students feel nervous and worried towards graduation. $73.4 \%$ of graduates are worried about the limited job opportunities available in Saudi job market. This is despite rapidly rising economy of Saudi Arabia. Next, $59.5 \%$ of graduates are worried about their future married life. Further, $53.4 \%$ feel worried about their inability to fulfill their financial needs. $58.1 \%$ of the graduates are worried about their families' future, while $41.4 \%$ of the graduates feel mentally and socially pressured by their families' worries about them. $54.7 \%$ of the graduates remain worried about their financial future and $64.9 \%$ are worried when they plan about their future. $55 \%$ fears failure to succeed. Further, $54.8 \%$ continues to think about their futures even during vacations, however, $22.7 \%$ are pessimistic about their future. Nonetheless, $82.3 \%$ believes that their majors of study (subject of specilaizations) would open the gates to their future and $57.2 \%$ of them views future life as happy. While $79.4 \%$ graduates are naturally optimistic, in $17.1 \%$ cases, students do not want to continue their studies but just overthink about their futures. In addition, 29.6\% graduates simply feel that job opportunities are decreasing. Finally, $15.5 \%$ graduates fails to be motivated to study. The next question (Table 9) of the research tried to probe the relations (if any) between future worries and the subject specialization (major of study)

Table 9 unfolds the relations between future worries and major of study (subject specialization). $60.7 \%$ of the participants believe that Saudi society does not value the fields of humanities. Unsurprisingly, this observation is not unique to Saudi Arabia alone. Indeed, many countries of both oriental and occidental worlds fail to value social sciences and humanities but showers importance to STEM and scientific courses (Bhattacharyya, 2009; 2013; Harding, 1986; Harding, 1986). ${ }^{2}$ Table 9 further reveals that $32.1 \%$ participants believe that subject specializations fail to provide a living. At the same time, $76 \%$ of the participants believe that academic excellence is the key to success. Yet again, $51.2 \%$ of the participants faced difficulties in choosing the right subject of specializations (major). In addition, $35.6 \%$ of the participants do not find their majors to be fulfilling of their intellectual and research ambitions. Besides, $54.2 \%$ of the participants are of their opinion that the teaching methods and curriculums are obsolete and fail to prepare them to be as researchers. Moreover, 52\% participants state that most graduates of their subject specializations remain unemployed for lacking the skills required by the employers. Further, $45.4 \%$ of the participants find curriculums to be incapable of making them independent. Finally, 20.5\% participants believe the reason behind their absence from lectures is their disinterest in their majors. All these contribute to a degree of worrying. One can easily conclude that there are relations between future worries and the type of subject selections by the youths in Saudi society.

In response to our next question on the reasons behind

2 The war against humanities at Britain's universities, The Guardian, retrieved from,

https://www.theguardian.com/education/2015/mar/29/war-against-humaniti es-at-britains-universities 
youths' future worries, the responses are illustrated in Table 10.

Table 10 reveals the most important reasons behind future worries. $53.4 \%$ participants seem to worry about that their qualifications would fail to buy them the skills required for qualifying in the changing job market, but $32.1 \%$ participants feel that they are unqualified to work for the private sector institutions due to lack of skills. While $53.9 \%$ of the participants feel that their future is endangered unless they find the right job, $51.6 \%$ continues to suffer from the society's negative view on them. Our survey also revealed that $61.5 \%$ of the participants feared about future unemployment. In addition, $51.3 \%$ participants expressed their fear of competing with the foreign workers.
Interestingly, nearly $50.5 \%$ participants were found to worry about expensive dowries. Finally, $56.8 \%$ participants reckoned that increase in unemployment might deprive them of a social status. These findings resonate with earlier studies, which state that the reasons behind future worries are multiple - financial, social, cultural or even genetic because of the new kind of worrying caused by anxiety and the mysterious future (Alfaltawi, 2007; Almasoud, 2005; Hejazy, 2008; Laylah, 1995).

Similarly, in response to our question about the impact of future worries on university youths' health, the responses received from the participants are displayed in Table 11.

Table 10. Reasons behind Future Worrying

\begin{tabular}{|c|c|c|c|c|c|c|c|c|c|c|}
\hline \multicolumn{3}{|c|}{ Statement } & $\begin{array}{c}\text { Strongly } \\
\text { agree }\end{array}$ & Agree & $\begin{array}{c}\text { No. } \\
\text { opinion }\end{array}$ & Disagree & $\begin{array}{l}\text { Strongly } \\
\text { disagree }\end{array}$ & $\bar{x}$ & S & Sequence \\
\hline \multirow{2}{*}{31.} & \multirow{2}{*}{$\begin{array}{l}\text { I am afraid: "my studies would not qualify me for } \\
\text { the changing job market." }\end{array}$} & $\#$ & 173 & 274 & 104 & 221 & 65 & \multirow{2}{*}{3.32} & \multirow{2}{*}{1.28} & \multirow{2}{*}{4} \\
\hline & & $\%$ & 20.7 & 32.7 & 12.4 & 26.4 & 7.8 & & & \\
\hline \multirow[t]{2}{*}{32.} & \multirow{2}{*}{$\begin{array}{l}\text { I feel like I am not qualified to work for the private } \\
\text { sector. }\end{array}$} & $\#$ & 97 & 172 & 111 & 306 & 151 & \multirow{2}{*}{2.71} & \multirow{2}{*}{1.29} & \multirow{2}{*}{8} \\
\hline & & $\%$ & 11.6 & 20.5 & 13.3 & 36.6 & 18.0 & & & \\
\hline \multirow[t]{2}{*}{33.} & \multirow{2}{*}{$\begin{array}{l}\text { I feel like my future is endangered unless I find the } \\
\text { right job. }\end{array}$} & $\#$ & 162 & 289 & 100 & 193 & 93 & \multirow{2}{*}{3.28} & \multirow{2}{*}{1.31} & \multirow{2}{*}{7} \\
\hline & & $\%$ & 19.4 & 34.5 & 11.9 & 23.1 & 11.1 & & & \\
\hline & \multirow{2}{*}{$\begin{array}{l}\text { Women still suffer from society's negative view } \\
\text { on them. }\end{array}$} & $\#$ & 181 & 251 & 128 & 189 & 88 & \multirow{2}{*}{3.30} & \multirow{2}{*}{1.31} & \multirow{2}{*}{5} \\
\hline & & $\%$ & 21.6 & 30.0 & 15.3 & 22.6 & 10.5 & & & \\
\hline & \multirow{2}{*}{ I fear thinking about future unemployment. } & $\#$ & 234 & 280 & 98 & 158 & 67 & \multirow{2}{*}{3.54} & \multirow{2}{*}{1.29} & \multirow{2}{*}{1} \\
\hline & & $\%$ & 28.0 & 33.5 & 11.7 & 18.9 & 8.0 & & & \\
\hline \multirow{2}{*}{\multicolumn{2}{|c|}{ 36. I fear competing with foreign workers. }} & $\#$ & 204 & 225 & 110 & 202 & 96 & \multirow{2}{*}{3.29} & \multirow{2}{*}{1.37} & \multirow{2}{*}{6} \\
\hline & & $\%$ & 24.4 & 26.9 & 13.1 & 24.1 & 11.5 & & & \\
\hline & \multirow{2}{*}{ I am worried about expensive dowry demands } & $\#$ & 193 & 229 & 158 & 179 & 78 & \multirow{2}{*}{3.33} & \multirow{2}{*}{1.29} & \multirow{2}{*}{3} \\
\hline & & $\%$ & 23.1 & 27.4 & 18.9 & 21.4 & 9.3 & & & \\
\hline & I am worried that increase in unemployment & $\#$ & 222 & 254 & 117 & 158 & 86 & 344 & 133 & 2 \\
\hline & would dwindle our social status. & $\%$ & 26.5 & 30.3 & 14.0 & 18.9 & 10.3 & 3.44 & 1.33 & 2 \\
\hline & & eral & erage $=$ & $28(\mathrm{No}$ & inion) & & & & & \\
\hline
\end{tabular}

Table 11. Future Worries Impact on University Youths' Health

\begin{tabular}{|c|c|c|c|c|c|c|c|c|c|c|}
\hline \multicolumn{3}{|c|}{ Statement } & $\begin{array}{l}\text { Strongly } \\
\text { agree }\end{array}$ & Agree & $\begin{array}{c}\text { No } \\
\text { opinion }\end{array}$ & Disagree & $\begin{array}{l}\text { Strongly } \\
\text { disagree }\end{array}$ & $\bar{x}$ & $\mathrm{~S}$ & Sequence \\
\hline \multirow{2}{*}{\multicolumn{2}{|c|}{ 39. I constantly suffer from insomnia. }} & \# & 221 & 226 & 60 & 210 & 120 & \multirow{2}{*}{3.26} & \multirow{2}{*}{1.44} & \multirow{2}{*}{1} \\
\hline & & $\%$ & 26.4 & 27.0 & 7.2 & 25.1 & 14.3 & & & \\
\hline \multirow[t]{2}{*}{40.} & \multirow{2}{*}{$\begin{array}{l}\text { I am afraid my health will be destroyed from } \\
\text { overthinking about the future. }\end{array}$} & $\#$ & 132 & 208 & 98 & 256 & 143 & \multirow{2}{*}{2.92} & \multirow{2}{*}{1.37} & \multirow{2}{*}{3} \\
\hline & & $\%$ & 15.8 & 24.9 & 11.7 & 30.6 & 17.1 & & & \\
\hline \multirow[t]{2}{*}{41.} & \multirow{2}{*}{$\begin{array}{l}\text { I suffer from stomach ulcer because of worrying } \\
\text { and thinking too much. }\end{array}$} & $\#$ & 103 & 90 & 85 & 319 & 240 & \multirow{2}{*}{2.40} & \multirow{2}{*}{1.33} & \multirow{2}{*}{7} \\
\hline & & $\%$ & 12.3 & 10.8 & 10.2 & 38.1 & 28.7 & & & \\
\hline \multirow[t]{2}{*}{42.} & \multirow{2}{*}{$\begin{array}{l}\text { I suffer from mental problems caused by thinking } \\
\text { about the future. }\end{array}$} & $\#$ & 76 & 130 & 90 & 311 & 230 & \multirow{2}{*}{2.42} & \multirow{2}{*}{1.28} & \multirow{2}{*}{6} \\
\hline & & $\%$ & 9.1 & 15.5 & 10.8 & 37.2 & 27.5 & & & \\
\hline & \multirow{2}{*}{$\begin{array}{l}\text { I am afraid of being diabetic or having a high } \\
\text { blood pressure. }\end{array}$} & $\#$ & 118 & 196 & 102 & 239 & 182 & \multirow{2}{*}{2.80} & \multirow{2}{*}{1.38} & \multirow{2}{*}{5} \\
\hline & & $\%$ & 14.1 & 23.4 & 12.2 & 28.6 & 21.7 & & & \\
\hline & \multirow{2}{*}{ I shake and sweat when I think about graduation. } & $\#$ & 70 & 100 & 96 & 306 & 265 & \multirow{2}{*}{2.29} & \multirow{2}{*}{1.26} & \multirow{2}{*}{8} \\
\hline & & $\%$ & 8.4 & 11.9 & 11.5 & 36.6 & 31.7 & & & \\
\hline \multirow{2}{*}{\multicolumn{2}{|c|}{ 45. I am afraid of epidemic diseases. }} & $\#$ & 113 & 214 & 103 & 221 & 186 & \multirow{2}{*}{2.82} & \multirow{2}{*}{1.38} & \multirow{2}{*}{4} \\
\hline & & $\%$ & 13.5 & 25.6 & 12.3 & 26.4 & 22.2 & & & \\
\hline & I feel nervous when I think about planning my & \# & 138 & 256 & 87 & 201 & 154 & 309 & 219 & 2 \\
\hline & future. & $\%$ & 16.5 & 30.6 & 10.4 & 24.0 & 18.4 & 3.09 & 2.19 & 2 \\
\hline & & eral & erage $=2$ & $75(\mathrm{No}$ & inion) & & & & & \\
\hline
\end{tabular}


Studies in psychology have shown relations between exhaustion and diseases; relations between fear of losing a job and diseases and relations between unemployment and distress where the subjects suffered from mental problems, depression, sadness, and hardship in making social relations (Lengfeld et al., 2009; Turiaux et.al, 2014). As demonstrated in Table $1153.4 \%$ participants suffer from insomnia followed by $40.7 \%$ who fear that their future might destroy their health. Besides, $23.1 \%$ are found to suffer from stomach ulcer because of too much thinking.

Moreover, our research unveiled that $24.2 \%$ participants suffer from mental problems caused by thinking about the future. While $37.5 \%$ participants fear being diabetic and suffering from high blood pressures, $20.3 \%$ participants sweat when they think about graduation, and 39.1\% participants are afraid of epidemic diseases. These findings match the observations made by scholars of Arab studies (Bozyan and Bogsah, 2012). However, research that is more rigorous is required to link these medical illnesses to worries. Our research also found that $47.1 \%$ participants feel nervous when they think about planning their future.

The next question of our survey was to probe the relations between future worries and phobia amongst the university youths (see, Table 12)

The responses as displayed in Table 12 unveils that 54.3\% participants believe that academic advising decreases future worries while $69.5 \%$ participants believe working fulfills future ambitions. While $24.1 \%$ participants feel that they are useless, the percentage of participants fearing isolation and marginalization stands at 33.7. Further, $18.3 \%$ participants stated that they felt like strangers around their own friends and families. Finally, 50.3\% participants see their academic failure as a path of being lost in life. Our research also found that majority of graduates suffers from exam fears, that is, fear to pass in the respective courses, thereby, suffers from a fear that dark future awaits for them. These forms of phobia exist in thoughts when the mind is occupied with the ideas of future risks, which in turn could affect their health.

The next question of our survey was to examine the relations between future worries and gender amongst university youths (Table 13).

Apparently, the findings from Table 13 demonstrate that $52.3 \%$ participants are worried about that academic career might be a block to building a perfect balance in maintaining family life, albeit $88.1 \%$ participants believe that the key to a happy marriage is understanding between husband and wife. In addition, unsurprisingly and as expected, 87.6\% participants anticipates that their spouses would understand their jobs.

Table 12. The Relations between Future Worries and Phobia amongst University Youths

\begin{tabular}{|c|c|c|c|c|c|c|c|c|c|c|}
\hline \multicolumn{3}{|c|}{ Statement } & $\begin{array}{c}\text { Strongly } \\
\text { agree }\end{array}$ & Agree & $\begin{array}{c}\text { No } \\
\text { opinion }\end{array}$ & Disagree & $\begin{array}{l}\text { Strongly } \\
\text { disagree }\end{array}$ & $\bar{x}$ & $\mathrm{~S}$ & Sequence \\
\hline \multirow{2}{*}{\multicolumn{2}{|c|}{$\begin{array}{l}\text { 47. I believe academic advising decrease future } \\
\text { worries. }\end{array}$}} & \# & 167 & 287 & 150 & 132 & 101 & \multirow{2}{*}{3.34} & \multirow{2}{*}{1.29} & \multirow{2}{*}{2} \\
\hline & & $\%$ & 20.0 & 34.3 & 17.9 & 15.8 & 12.1 & & & \\
\hline & \multirow{2}{*}{$\begin{array}{l}\text { I cannot achieve my future goals and personal } \\
\text { ambitions without working. }\end{array}$} & \# & 234 & 347 & 106 & 105 & 45 & \multirow{2}{*}{3.74} & \multirow{2}{*}{1.15} & \multirow{2}{*}{1} \\
\hline & & $\%$ & 28.0 & 41.5 & 12.7 & 12.5 & 5.4 & & & \\
\hline \multirow{2}{*}{\multicolumn{2}{|c|}{ 49. I sometimes feel useless. }} & \# & 78 & 124 & 104 & 285 & 246 & \multirow{2}{*}{2.41} & \multirow{2}{*}{1.30} & \multirow{2}{*}{5} \\
\hline & & $\%$ & 9.3 & 14.8 & 12.4 & 34.1 & 29.4 & & & \\
\hline \multirow{2}{*}{\multicolumn{2}{|c|}{ 50. I fear isolation and marginalization. }} & \# & 94 & 188 & 115 & 267 & 172 & \multirow{2}{*}{2.78} & \multirow{2}{*}{2.32} & \multirow{2}{*}{4} \\
\hline & & $\%$ & 11.2 & 22.5 & 13.7 & 31.9 & 20.5 & & & \\
\hline \multirow{2}{*}{\multicolumn{2}{|c|}{ 51. I feel like a stranger around my family and friends. }} & \# & 55 & 98 & 104 & 313 & 267 & \multirow{2}{*}{2.24} & \multirow{2}{*}{1.20} & \multirow{2}{*}{6} \\
\hline & & $\%$ & 6.6 & 11.7 & 12.4 & 37.4 & 31.9 & & & \\
\hline \multirow[t]{2}{*}{52.} & \multirow{2}{*}{$\begin{array}{l}\text { I believe academic failure is the path to being lost } \\
\text { in life. }\end{array}$} & \# & 203 & 218 & 86 & 184 & 146 & \multirow{2}{*}{3.18} & \multirow{2}{*}{1.46} & \multirow{2}{*}{3} \\
\hline & & $\%$ & 24.3 & 26.0 & 10.3 & 22.0 & 17.4 & & & \\
\hline
\end{tabular}

Table 13. The Relations between Future Worries and Gender among University Youths

\begin{tabular}{|c|c|c|c|c|c|c|c|c|c|c|}
\hline \multicolumn{3}{|c|}{ Statement } & $\begin{array}{c}\text { Strongly } \\
\text { agree }\end{array}$ & Agree & $\begin{array}{c}\text { No } \\
\text { opinion }\end{array}$ & Disagree & $\begin{array}{l}\begin{array}{l}\text { Strongly } \\
\text { disagree }\end{array} \\
\end{array}$ & $\overline{\boldsymbol{x}}$ & $\mathrm{S}$ & Sequence \\
\hline \multirow{2}{*}{\multicolumn{2}{|c|}{$\begin{array}{l}\text { 53. I am worried that being behind academically } \\
\text { affects building a family. }\end{array}$}} & $\#$ & 185 & 253 & 107 & 193 & 99 & \multirow{2}{*}{3.28} & \multirow{2}{*}{1.35} & \multirow{2}{*}{3} \\
\hline & & $\%$ & 22.1 & 30.2 & 12.8 & 23.1 & 11.8 & & & \\
\hline & \multirow{2}{*}{ Understanding is the key to a happy marriage. } & $\#$ & 457 & 280 & 62 & 19 & 19 & \multirow{2}{*}{4.36} & \multirow{2}{*}{0.89} & \multirow{2}{*}{2} \\
\hline & & $\%$ & 54.6 & 33.5 & 7.4 & 2.3 & 2.3 & & & \\
\hline \multirow{2}{*}{\multicolumn{2}{|c|}{ 55. I hope my spouse understands my job }} & $\#$ & 497 & 236 & 68 & 20 & 16 & \multirow{2}{*}{4.41} & \multirow{2}{*}{0.88} & \multirow{2}{*}{1} \\
\hline & & $\%$ & 59.4 & 28.2 & 8.1 & 2.4 & 1.9 & & & \\
\hline \multicolumn{11}{|c|}{ General Average $=4.01$ (Agree) } \\
\hline
\end{tabular}


It is well documented that the female-societal values are different from those of the males in Saudi society. Hence, the degree and the nature of worrying too differs from female graduates to male graduates, which is due to the culture of the society. Arguably, the findings of the statements of Table 13 reflect the worries entailed especially in the mindsets of women and that too in a society where patriarchal values are deeply entrenched. A female graduate lives in an environment dictated by both traditional and modern roles. However, the key to career success of a woman depends mostly on her husband's understanding. Scholars argue that females want to escape traditional roles and continue their studies, and try to maintain balance between paid work and family (Allemendinger et. al. lebenseNtwürfe von jungen Und Maedchen in Bayern 2013, see also Bhattacharyya, 2009; 2013). However, we argue that while European woman sacrifices motherhood for the sake of establishing a career, for an Arab woman, family is central, this kindles worries about her ability to maintain a perfect balance between work and family. On this ground, we disagree with the study made by Alshafi'a (1996), who claimed that it is the males, who worry more about the future than the females. Males' worries are money-oriented while the worries of females are a mix of both modern and traditional values. With no doubt, males and females' values differ in accordance with personalities and expectations. In Saudi society, one can easily witness that males are capable of performing roles of power while females are still incapable of performing similar roles (Al-Shahrani, 2016; Shalhoub, 2015). For instance, women are disallowed to seek even government services without the presence or permission of a male member of the family (husband/father) (Al-Shahrani, 2016; Shalhoub, 2015). Clearly, this shows that women in Saudi society remain under the heavy protection of men. American scientist, Martha Nussbaum, calls male dominance as Narcissistic attitudes (here, it could be even labelled as male chauvinism) signaling something, which is common amongst most men. As a result, worries about the future are more serious amongst men than they are amongst women, who are likely to suffer from depression because the men carry the burden of looking after and protecting the women of their respective families. This is why the nature and the degree of future worries are different for both males and females. Perhaps, what increases female graduates' anxiety towards the future are the social views on women. In the said context, from our findings, it can be argued that while a male graduate's worry is narcissistic, a female graduate's worry is all about enabling and empowering.

The final question of our survey was about the stance of university youths towards worries about the future?

In order that the graduates become free from future worries, and as demonstrated by the statements displayed in Table 14, majority of the students seek for a curriculum that promotes a culture of innovation and entrepreneurship amongst graduates, which eventually could be a road to remove future career/job worries and meet the demands of the international job market.

From the above analysis, it can be argued that while $\mathrm{H}_{0}$ is rejected, $\mathrm{H}_{1}$ could be accepted. Our findings support the notion of worrying as put forward by Sigmund Freud (1989). Indeed, a graduate faces so many academic, mental, and social pressures created by their cultural and social surroundings. In reality however, given the deeply rooted traditional socio-cultural values of Saudi society, while female graduates suffer from academic, social and mental pressures (like good education, successful marriage, work-life balance), the worries the male graduates are different and span from building a career, having a secured job to looking after his family. However, overall findings suggest that graduates are often found to worry when they think about what the future holds for them.

Table 14. The Stance of University Youths towards Worries about the Future

\begin{tabular}{|c|c|c|c|c|c|c|c|c|c|c|}
\hline \multicolumn{3}{|c|}{ Statement } & $\begin{array}{c}\text { Strongly } \\
\text { agree }\end{array}$ & Agree & $\begin{array}{l}\text { No. } \\
\text { opinion }\end{array}$ & Disagree & $\begin{array}{l}\text { Strongly } \\
\text { disagree }\end{array}$ & $\bar{x}$ & $\mathrm{~S}$ & Sequence \\
\hline \multirow[t]{2}{*}{56.} & \multirow{2}{*}{$\begin{array}{l}\text { Promote a culture of innovation and } \\
\text { entrepreneurship amongst graduates. }\end{array}$} & \# & 455 & 280 & 79 & 11 & 12 & \multirow{2}{*}{4.38} & \multirow{2}{*}{0.82} & \multirow{2}{*}{1} \\
\hline & & $\%$ & 54.4 & 33.5 & 9.4 & 1.3 & 1.4 & & & \\
\hline \multirow[t]{2}{*}{57.} & \multirow{2}{*}{$\begin{array}{l}\text { Overcome failure with willpower and } \\
\text { commitment. }\end{array}$} & \# & 431 & 311 & 66 & 17 & 12 & \multirow{2}{*}{4.35} & \multirow{2}{*}{0.83} & \multirow{2}{*}{2} \\
\hline & & $\%$ & 51.5 & 37.2 & 7.9 & 2.0 & 1.4 & & & \\
\hline \multirow[t]{2}{*}{58.} & \multirow{2}{*}{$\begin{array}{l}\text { Modern academic preparation is the best future } \\
\text { investment. }\end{array}$} & $\#$ & 369 & 286 & 113 & 47 & 22 & \multirow{2}{*}{4.11} & \multirow{2}{*}{1.01} & \multirow{2}{*}{5} \\
\hline & & $\%$ & 44.1 & 34.2 & 13.5 & 5.6 & 2.6 & & & \\
\hline \multirow[t]{2}{*}{59.} & \multirow{2}{*}{$\begin{array}{l}\text { Academic excellence is a good resource in the } \\
\text { future. }\end{array}$} & $\#$ & 420 & 272 & 68 & 55 & 22 & \multirow{2}{*}{4.21} & \multirow{2}{*}{1.02} & \multirow{2}{*}{4} \\
\hline & & $\%$ & 50.2 & 32.5 & 8.1 & 6.6 & 2.6 & & & \\
\hline \multirow[t]{2}{*}{60.} & \multirow{2}{*}{$\begin{array}{l}\text { Development of curriculums to meet the } \\
\text { international job market's demands. }\end{array}$} & $\#$ & 461 & 247 & 86 & 23 & 20 & \multirow{2}{*}{4.32} & \multirow{2}{*}{0.94} & \multirow{2}{*}{3} \\
\hline & & $\%$ & 55.1 & 29.5 & 10.3 & 2.7 & 2.4 & & & \\
\hline \multicolumn{11}{|c|}{ General Average $=4.28$ (Agree) } \\
\hline
\end{tabular}




\section{Conclusions}

This research set out to examine the worries about the future of the youths pursuing graduation in three Saudi Universities. The findings suggest that all youths considered for this study suffer from some kind of worries but the worries are gendered and the kind, nature and the degree of worries differs from males and females. As stated in the introduction that youths' worries about their futures are highly under-researched in Saudi Arabia. In this sense, this is one of the first studies on Saudi students' worries about their futures. While this research is an addition to the research on worries in Saudi psychology, perhaps, this research can be replicated to conduct a larger study, which would enable to capture the subtle issues connected to psychology of worries.

\section{REFERENCES}

Al-Shahrani,Hind Bint Faie (2016). Strategies to Empower Saudi Women's Educational

Attainment and Work, International Journal of Social Work and Human Services Practice, 4 (1), 1-6

Bhattacharyya, R. (2013). Are We Empowered? Stories of young Indian working women, Saarbrücken, Germany: Lap Lambert Academic Publishing, (ISBN: 978-3-659-20580-4)

Bhattacharyya, R (2009). Examining the Changing Status and Role of Middle Class Assamese Women: Lessons from the Lives of University Students, $\mathrm{PhD}$ thesis, Newcastle University, UK

Shalhoub, Haifa Abdul Rahman Saleh (2015). Empowering Saudi Women through Social Welfare

Policies in Judiciary, International Journal of Social Work and Human Services Practice, 3 (5), 163-168

Julian Turiaux and Cordula Krinner: gestresst im Studium? Vergleich studierender Hochschultypen und eine explorative Analyse potentieller Stressoren, Journal of Business and Media Psychologie , 2014, Heft 1

Linden, M. et.al.: ein Selstbeurteilungsfragebogen zur Erfassung arbeitsezogener Aengste, Berlin,2010

Lengfeld, H. u.a.: Die Angst der Mittelschicht: in Zeitschrift fuer Soziologie, Jg.38,Heft 5, Oktober, 2009

Regenbogen, A.:Sozialisation in den 90er Jhren, Opladen , 1998

Ulrich Teichler: Potentiale und Ertraege vonAbsolventenstudien, in "Sozialwissenschaften und Berufspraxis, (Hrsg) vom Berufsvrband deutscher Soziologinnen und Soziologen, Jahrgang (25), 2002, 10 Intitut fuer ugendforschung,jugendstudie 2011

Spegelonline.De Aengste der Deutchen, 2009

EURopaeische Absolventenstudie, 2000

Warum Frauen Aengstlicher als Maenner (Intern)
Allemendinger, J. et.al. Lebensentwuerfe junger Frauen und Maenner in Bayern, im Auftrag der friedrich Ebert Stiftung 1999. Noch benachteiligt? Absolventinnen auf dem Arbeitsmarkt,in :

Sozialwissenschaften und Berufspraxis, Jahrgang (25), 2002

Institut fuer Hochschulforschung: Junge Akademiker im Glueck, ich studiere, also bin ich im Glueck, Berlin

Petri, Horst: Zukuftaengse von Kindern und Jugendlichen, in: Zeitschrift fuer Sozialisationsforschung und erziehugssoziologie (16) 1996

Ahmad, Hasanain Ahmad, 2000: "Future Anxiety and Exam Anxiety in their Relation to Some Psychological Variables in a Sample of High School Students", Master's Thesis (Unpublished), College of Arts, University of Cairo

Tapscott, Don, 2012: "The Net Generation, How the Net Generation is Changing Our World", Cairo

Toffler, Alvin, 1990: "Future Shock" (Translation by Mohammed Ali Nassif and Ahmad Kamal Abualmajd). Cairo

Hassan, Ahmad Mohammed, 2000: "Future Anxiety and Exam Anxiety in their Relation to Some Psychological Variables in a Sample of Second-Year High School Students", Master's thesis (Unpublished), Almaniah

Hijazi, Mustapha, 2000: "Gulf Youth and the Future, an Analytical Psychological-Social study”, Beirut

Hussein, Abdullah Ghloum and Abdulra'ouf Abdulaziz Aljirdawi, 1985: "Youth Trends and Issues - an Applied Study" In: Studies and Issues of the Arab and Gulf Societies, Special Issue, Published by the Office of Observation for the Council of Labor and Social Affairs Ministers in Arab and Gulf States, Bahrain, Issue 5, July, Riyadh

Beck, Ulrich, 2009: "Risk Society" (Translation by George Kattorah), Beirut

Khayyat, Abdullatif, 1974: “Alvin Toffler, Future Shock”, Beirut

Dawood et al, 1991: "Personality between Health and Illness", Cairo

Al Fitlawi, Ali, 2007: "Journal of the Union of Arab Colleges of Education and Psychology"

Al Fitlawi, Ali, 2010, "Psychology of Time”, Damascus

Alkayyal, Dahham, 1990, "The relation of Anxiety with Mental Guilt", an experimental study, Baghdad

Abdulsalam, Alsayyid Abduldayim, 1996: "The Perspective of Future Time as a Motivating Concept in Education and its Relation with Gender, Major, and Academic Achievement in the Students of the College of Education", University of Zagazig, Journal of Psychological Research, Issue 4 vol. 5

Alshafi'i, Ri'fat Ahmad, 1996: "Parental Trends as Perceived by their Children and its Relation to their Conception of the Future", Master's thesis (Unpublished), Institute of Higher Studies for Childhood, University of Ain Shams

Alhamadani, Iqbal Mohammed Rashid, 2011: “Alienation Rebellion - Future Anxiety", Amman

Shugair, Zainab Mahmoud, 2005: "Measure of Future Anxiety", Cairo 
AbdulBaqi, Salwa, 1993: "Causes of Anxiety, Past Experiences, the Present, and the Future and Future Fears", Psychological and Social Studies G(58), Alam Alkitab, Cairo

Freud, Sigmund, 1989: "Inhibitions, Symptoms and Anxiety", Translation by Mahmoud Othman Nagaty, Cairo

Almash'aan, Ouid, 2000: "The Drive for Achievement and its Relation with Anxiety and Confidence in Kuwaiti and Non-Kuwaiti Civil Employees", Annals of Arts and Social Sciences Newsletter 139, annual 20, Kuwait

Leilah, Ali, 1990: "Youth in Society", Series of Contemporary Sociology, Cairo

Leilah, Ali, 1995: "Youth in a Changing Society, Meditations upon Biological Phenomena and Violence", Alexandria

Masoud, Sanaa Munir, 2006: "A Few Variables Linked to Future Anxiety", Master's thesis (unpublished), College of Education, Egypt

Mu'awwadh, Abdultawwab et al, 1996: "The Effects of Educational, Psychological, and Religious Therapies, Respectively, in Reducing Future Anxiety in a Sample of University Students" Doctoral dissertation (unpublished), College of Education in University of Tanta
Morin, Edgar, 2004: "Thought and the Future, Introduction to Complex Thought", Casablanca

Mahmoud, Shamal Hassan, 1999: "Future Anxiety in College-Graduate Youth", Journal of Arabic Future, Issue 249, November.

Hall, Calvin, 1990: "Principals of Freudian Psychology" (Translation by Dahham Alkayyal), Cairo

Harding, J. (1986). Perspectives on Gender and Science, London: Falmer

Harding, S. (1986). The Science Question in Feminism, Milton Keynes: Open University Press

Jung, 2000: "The Foundations of Human Personality" (Translation by Nihad Khayyatah), Latakia

Collin Wilson, 1969, "The Non-Belonging” (Translation by Zaki Hassan), Beirut

Linda L. Davidoff, 2009: “Introduction to Psychology”, Riyadh Alhuaij, Almahdi Salih: "A Study on Psychological Pressures" 